\title{
KEBIJAKAN DEVIDEN DAN CAPITAL GAIN: PENGARUHNYA TERHADAP HARGA SAHAM
}

\author{
Devident Policy And Capital Gain: The Effect On Stock Prices \\ Lisa Kustina, Otika Safitri \\ STIE Pelita Bangsa Bekasi \\ Lisakustina188@gmail.com,otikasafitri@gmail.com \\ Samsul Anwar \\ FE Unwir Indramayu \\ anwar_909@yahoo.com
}

\begin{abstract}
ABSTRAK
Penelitian ini bertujuan untuk mengetahui pengaruh kebijakan deviden dan capital gain terhadap harga saham. Penelitian ini menggunakan data sekunder. Jumlah sample dalam penelitian ini ada 15 perusahaan LQ45 yang menerbitkan saham dan membagikan deviden ataupun capital gain berturut-turut pada tahun 2014-2015. Variabel independen yang digunakan dalam penelitian ini adalah Capital gain dan Kebijakan Deviden, sedangkan variable dependen yang digunakan dalam penelitian ini adalah harga saham. Pengujian hipotesis ini menggunakan uji regresi linear data panel dan diolah dengan menggunakan software eviews. Hasil penelitian ini menunjukan bahwa variable kebijakan deviden tidak berpengaruh secara signifikan terhadap harga saham dan variable capital gain berpengaruh secara signifikan terhadap harga saham pada perusahaan LQ45 tahun 2014-2015.
\end{abstract}

Kata kunci: Capital gain, Kebijakan Deviden, Harga saham

\footnotetext{
ABSTRACT

This study aims to determine the effect of dividend policy and capital gain on stock prices. This study uses secondary data. The number of samples in this study were 15 LQ45 companies that issued shares and distributed dividends or capital gains in a row in 2014-2015. The independent variable used in this study is Capital gain and Dividend Policy, while the dependent variable used in this study is the stock price. Testing this hypothesis uses a linear data panel regression test and processed using software eviews. The results of this study indicate that the dividend policy variable does not significantly influence stock prices and variable capital gains significantly influence stock prices in LQ45 companies in 2014-2015.
}

Keywords: Capital gain, dividend policy, stock price

\section{PENDAHULUAN}

Perekonomian di Indonesia mengalami pertumbuhan dari waktu ke waktu, dimana pertumbuhan tersebut sejalan dengan era globalisasi ekonomi. Dengan semakin bertumbuhnya ekonomi akan mengakibatkan terjadinya perubahan nilai kehidupan masyarakat, pola pikir, pola hidup, dan tingkah laku. Masyarakat masa kini memiliki keinginan yang semakin meningkat untuk menginvestasikan dananya, baik dalam bentuk saham, deposito, atau dalam bentuk investasi lainnya (Prily, et al: 2017). Dalam berinvestasi para investor memerlukan informasi yang akurat yang akan digunakan sebagai pertimbangan dalam menentukan pilihan untuk membeli saham-saham perusahaan yang menguntungkan. Informasi yang ada dapat digunakan sebagai bahan analisa saham baik secara fundamental maupun teknikal. Informasi yang bersifat fundamental diperoleh dari kondisi intern prusahaan dan informasi yang bersifat 
teknikal diperoleh dari luar perusahaan seperti ekonomi, politik, finansial dan faktor lainnya. Informasi fundamental dan tekhnikal tersebut dapat digunakan sebagai dasar bagi investor untuk memprediksi capital gain, risiko atau ketidak pastian, jumlah, waktu dan faktor lain yang berhubungan dengan investasi di pasar modal. Informasi yang diperoleh dari kondisi intern perusahaan yang lazim digunakan adalah laporan keuangan dan data deviden. Laporan keuangan sebagai sumber data dalam analisa fundamental harus mampu menggambarkan posisi keuangan perusahaan pada waktu tertentu serta hasil operasi pada waktu tertentu secara wajar. Keadaan ini diharapkan dapat memenuhi kebutuhan para pemakai untuk mendukung proses pengambilan keputusan investasi dipasar modal (Melani: 2017).

Saham mempunyai resiko yang paling tinggi diantara semua jenis instrument investasi. Perangkat analisis yang dapat digunakan dalam penilaian dan penawaran harga saham serta kelayakan ialah analisis fundamental dan analisis teknikal. Harga saham akan naik apabila pendapatan perusahaan mengalami peningkatan secara terus menerus dan konsisten (Kurniawan \& Surihadi; 2015). Meskipun saham mempunyai tingkat resiko yang tinggi namun para investor banyak yang tertarik untuk menginvestasikan dananya dalam bentuk saham, karena akan ada dua keuntungan yang akan diterima oleh pemegang saham yaitu berupa capital gain dan deviden.
Lisa Kustina, Otika Safitri dan Samsul Anwar

Hasil penelitian Natalia \& Kalangi (2016) menghasilkan kesimpulan selisih harga saham tidak berbeda secara signifikan dengan deviden per lembar saham. Ini mengindikasikan tidak terjadinya anomali pasar. Kondisi ini dapat terjadi karena ketidakpedulian terutama di kalangan investor individual terhadap perbedaan besaran tarif pajak dari deviden dan capital gain. Abdullah (2013) menyatakan bahwa reaksi perdagangan saham tidak berpengaruh terhadap pengumuman deviden. Rahmawati (2017) menyatakan bahwa kebijakan pembagian deviden yang dilakukakan oleh perusahaan transportasi tidak memberikan dampak yang signifikan terhadap perubahan harga saham. Kurniawan \& Surihadi (2015) menyatakan bahwa ada pengaruh secara bersama sama variabel harga saham, ukuran perusahaan dan risiko saham terhadap required of return saham pada industri manufaktur yang terdaftar di BEI. Berdasarkan latar belakang tersebut, maka peneliti ini akan meneliti mengenai "Kebijakan Deviden Dan Capital Gain: Pengaruhnya Terhadap Harga Saham”.

Perumusan masalah dalam penelitian ini adalah:

1. Apakah kebijakan deviden berpengaruh terhadap harga saham?

2. Apakah capital gain berpengaruh terhadap harga saham? 
Lisa Kustina, Otika Safitri dan Samsul Anwar

\section{TINJAUAN PUSTAKA}

\section{Harga Saham}

Saham banyak dipilih oleh para investor dikarenakan saham bisa memberi tingkat keuntungan yang menarik. Saham adalah surat berharga yang menunjukan kepemilikan perusahaan sehingga pemegang saham memiliki hak klaim atas deviden atau distribusi lain yang dilakukan perusahaan kepada pemegang saham termasuk hak klaim atas asset perusahaan dengan prioritas setelah hak klaim pemegang surat berharga lain dipenuhi jika terjadi likuiditas (Kurniawan \& Surihadi: 2015).

Menurut Hutami (2012) harga saham adalah harga selembar saham yang terjadi pada saat tertentu yang ditentukan oleh permintaan dan penawaran di pasar modal. Investor yang menanamkan dananya pada saham-saham perusahaan sangat berkepentingan terhadap laba saat ini dan laba yang diharapkan di masa yang akan datang serta adanya stabilitas laba. Sebelum menanamkan dananya, investor melakukan analisis terhadap kemampuan perusahaan untuk menghasilkan laba. Investor hanya akan menginvestasikan dananya kepada perusahaan yang mempunyai reputasi baik. Perusahaan yang mempunyai reputasi baik adalah perusahaan yang mampu memberikan deviden secara konstan kepada pemegang saham. Semakin meningkatnya laba yang diterima perusahaan maka semakin tinggi pula deviden yang dibayarkan perusahaan kepada pemegang saham, namun jika pemegang saham mengharapkan keuntungan dalam periode yang pendek maka mengharapkan perusahaan yang harga jual saham rendah sehingga capital gain yang didapatkan besar (Rinati: 2009).

Salah satu konsep dasar dalam manajemen keuangan adalah bahwa tujuan yang ingin dicapai manajemen keuangan adalah memaksimalkan nilai perusahaan. Bagi perusahaan yang telah go public, tujuan tersebut dapat dicapai dengan cara memaksimalkan nilai pasar harga saham yang bersangkutan. Dengan demikian pengambilan keputusan selalu didasarkan pada pertimbangan terhadap maksimalisasi kekayaan para pemegang saham. Suatu informasi yang diberikan perusahaan melalui laporan keuangan dapat dijadikan sinyal bagi investor untuk pengambilan keputusan dalam berinvestasi. Jika laporan tersebut memberikan nilai yang positif, maka diharapkan pasar dapat memberikan reaksi.

\section{Deviden}

Deviden merupakan nilai pendapatan bersih perusahaan setelah pajak dikurangi dengan laba ditahan (retained earnings) yang besarnya diputuskan oleh Rapat Umum Pemegang Saham (RUPS). Setiap pemegang saham berhak atas bagian laba yang dibagikan atau deviden sesuai dengan proporsi kepemilikannya, jika perusahaan memperoleh keuntungan (Erdianza: 2017). Deviden yang dibayarkan dapat berupa deviden tunai (cash 
Lisa Kustina, Otika Safitri dan Samsul Anwar

devidend) dan deviden saham (stock dibayarkan pada pemegang saham tergantung devidend). Deviden tunai merupakan deviden yang dibayarkan dalam bentuk uang tunai, sedangkan deviden saham merupakan deviden yang dibayarkan dalam bentuk saham dengan poporsi tertentu. Nilai suatu deviden tunai sesuai dengan nilai tunai yang dibayarkan, sedangkan nilai dari deviden saham dihitung dari rasio antara deviden per lembar saham (DPS) terhadap harga pasar per lembar saham (Nilamsari \& Supatmi: 2015).

Kebijakan deviden menjadi salah satu alasan bagi investor untuk menanamkan modalnya kepada perusahaan. Pembagian deviden tersebut akan menjadikan seorang investor mengambil keputusan untuk mempertahankan atau menjual saham yang dimiliki. Prosentase dari laba yang akan dibayarkan kepada pemegang saham sebagai cash devidend disebut Devidend Payout Ratio (Wiradharma, et al: 2014). Devidend Payout Ratio (DPR) yaitu persentase laba yang dibayarkan dalam bentuk deviden dan penentu jumlah laba yang akan dapat ditahan dalam sebuah perusahaan, juga sebagai penentu berapa laba deviden yang akan dibagi kepada para investor. Laba yang dibagikan dalam bentuk deviden akan menambah kepercayaan investor untuk menanamkan modalnya di perusahaan. Pemegang saham lebih menyukai deviden tinggi dibandingkan dengan deviden yang akan dibagikan di masa yang akan datang atau capital gain (Suffah dan Riduan, 2016). Proporsi deviden yang pada kemampuan perusahaan menghasilkan laba serta bentuk kebijakan deviden yang diterapkan oleh perusahaan yang bersangkutan (Ismawati, 2017).

Investor mengharapkan deviden yang diterimanya dalam jumlah besar dan mengalami peningkatan setiap periode. Deviden ratio yang tinggi mencerminkan perusahaan memiliki prospek yang baik dan akan menarik investor yang memanfaatkan deviden untuk keperluan konsumsi. Apabila deviden yang diterima naik tentu saja hal ini akan menarik investor untuk membeli saham perusahaan tersebut. Dengan banyaknya saham yang dibeli maka harga saham perusahaan tersebut akan naik (Aminah, Arifati, \& Supriyanto: 2016).

Menurut Ainun (2013) menyatakan kebijakan deviden merupakan kebijakan yang sangat penting bagi manajer keuangan karena melibatkan dua pihak yaitu pemegang saham dan perusahaan yang keduanya mempunyai kepentingan berbeda. Kebijakan deviden adalah kebijakan yang berkaitan dengan pembayaran deviden oleh perusahaan, berupa penentuan besarnya pembayaran deviden dan besarnya laba yang ditahan untuk kepentingan perusahaan, stabilitas deviden dan pertumbuhan deviden. Apabila deviden akan dibayarkan semua, kepentingan cadangan akan terabaikan, sebaliknya apabila laba akan ditahan semua tanpa ada pembagian deviden, kepentingan pemegang saham akan uang kas 
Lisa Kustina, Otika Safitri dan Samsul Anwar

terabaikan. Untuk menjaga kedua capital yang tinggi membuat biaya-biaya kepentingan, manajer keuangan dapat yang dikeluarkan oleh perusahaan juga menempuh kebijakan deviden yang optimal.

\section{Capital Gain}

Capital gain yaitu selisih antara harga saham pada periode ini dengan harga saham pada periode sebelumnya. Capital gain disebut juga sebagai capital actual. Capital gain sangat tergantung dari harga saham instrument investasi, yang berarti bahwa instrument investasi harus diperdagangkan dipasar. Dengan adanya perdagangan maka akan timbul perubahan nilai suatu instrument investasi yang memberikan capital gain. Besarnya capital gain dengan cara menghitung return histories yang terjadi pada periode sebelumnya, sehingga dapat ditentukan besarnya tingkat kembalian yang diinginkan (Nilamsari \& Supatmi: 2015).

Informasi intellectual capital sangat dibutuhkan bagi investor dalam pertimbangan keputusan berinvestasi, apalagi jika perusahaan tersebut mampu mengungkapkan informasi intellectual capital yang baik. Hal ini menyebabkan kepercayaan investor terhadap keberlangsungan perusahaan kedepannya pun meningkat, dengan begitu permintaan saham atas perusahaan akan naik. Keadaan tersebut berdampak pada naiknya harga saham dan return saham ikut terpengaruh dengan adanya peningkatan yang menyebabkan perolehan capital gain pun tinggi ketika saham tersebut dijual. Namun di sisi lain, penciptaan nilai tambah intellectual berlebihan sehingga membuat perusahaan cenderung boros dalam memanfaatkan kekayaan (dana) yang ada. Sehingga hal ini akan direspon negatif bagi para investor karena dianggap tidak mendatangkan keuntungan di masa mendatang, dimana dalam hal ini ditandai dengan perolehan capital gain yang kecil (Nilamsari \& Supatmi: 2015).

Faktor-faktor yang mempengaruh return saham (capital gain) terdiri dari faktor makro dan faktor mikro. Faktor makro adalah faktor yang berada di luar perusahaan terdiri dari faktor makro ekonomi seperti tingkat inflasi, dan faktor non ekonomi meliputi peristiwa politik dalam negeri, peristiwa politik luar negeri, peperangan, dan kasus lingkungan hidup. Faktor mikro merupakan faktor yang berada dalam perusahaan itu sendiri yaitu laba bersih, nilai buku, dan rasio keuangan lainnya (Indriastuti \& Nafiah, 2017).

\section{Hipotesis Penelitian}

Kebijakan deviden merupakan keputusan mengenai apakah laba yang diperoleh perusahaan akan dibagikan kepada para pemegang saham sebagai deviden atau akan ditahan dalam bentuk laba ditahan guna pembiayaan investasi dimasa yang akan datang. Hutami (2012), menyatakan bahwa devidend per share berpengaruh positif dan signifikan terhadap harga saham perusahaan 
Lisa Kustina, Otika Safitri dan Samsul Anwar

industri manufaktur yang terdaftar di BEI. Sedangkan variable independen yang Berdasarkan hal tersebut maka hipotesis yang dapat dikembangkan adalah

H1 : Kebijakan deviden berpengaruh terhadap harga saham.

Capital gain merupakan keuntungan yang diperoleh investor sehubungan dengan penjualan saham di pasar sekunder yang dilakukan, dengan kondisi harga jualnya di atas harga beli. Kurniawan \& Surihadi, (2015) menyatakan bahwa ada pengaruh secara bersama sama variabel harga saham, ukuran perusahaan dan risiko saham terhadap required of return saham pada industry manufaktur. Berdasarkan hal tersebut maka hipotesis yang dapat dikembangkan adalah

H2 : Capital gain berpengaruh terhadap harga saham

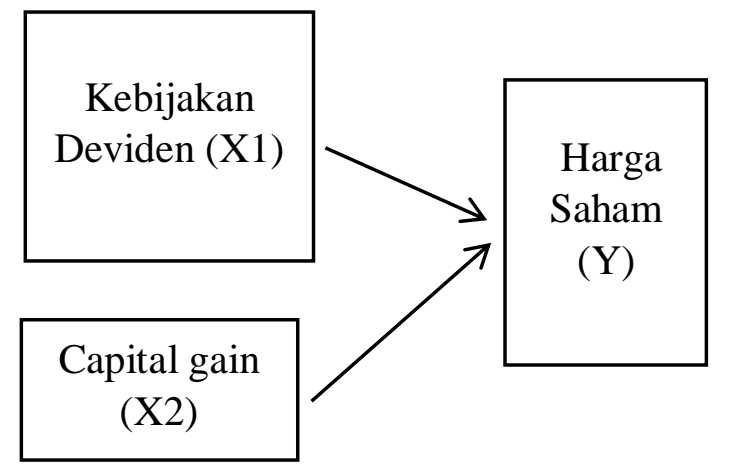

\section{METODOLOGI PENELITIAN}

Jenis penelitian ini adalah penelitian kuantitatif. Variable dependen dalam penelitian ini adalah harga saham. Harga saham yang digunakan dalam penelitian ini adalah menggunakan harga saham penutupan yang dipublikasikan di Bursa Efek Indonesia.

\section{PEMBAHASAN}

Untuk menentukan model yang tepat di dalam penelitian ini, common effect atau fixed effect, maka dilakukan chow test. Apabila probabilitas Chisquare lebih dari 0,05 maka model yang tepat adalah common effect, dan apabila kurang dari 0,05 maka harus diuji 
Lisa Kustina, Otika Safitri dan Samsul Anwar

kembali dengan Hausman Test. Apabila Dari tampilan output eviews diatas dapat kurang dari 0,05 maka model yang dipilih ada dilihat hasil redundant fixed effect atau fix effect, tetapi jika hasilnya lebih dari 0,05 likelihood ratio untuk model ini memiliki nilai maka harus di uji kembali dengan lagrange probabilitas F lebih kecil dari pada Alpha multiple test.

\section{Uji F Resticted (Chow Test)} $(0,05)$ sehingga common effect ditolak dan fixed effect diterima, model yang sesuai dari

Hasil Uji Chow hasil ini yaitu fixed effect (Karena nilai probabilitas F sebesar $0,0000<0,05)$.

Redundant Fixed Effects Tests

Equation: Untitled

Test cross-section fixed effects

\section{Uji Hausman}

\begin{tabular}{|c|c|c|c|}
\hline Effects Test & Statistic & Correlated Random Elflects & - Hausman Test \\
\hline Cross-section F & 16.112934 & 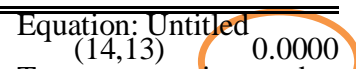 & \\
\hline Cross-section Chi-square & 87.292795 & $\begin{array}{cc}\text { Test cross-section random } \\
14\end{array}$ & ffects \\
\hline
\end{tabular}

\begin{tabular}{|c|c|c|c|c|c|c|}
\hline \multirow{2}{*}{\multicolumn{2}{|c|}{ Cross-section fixed effects test equation: }} & & "Test Summary & \multicolumn{2}{|c|}{ Chi-Sq. Statistic } & Chi-Sq. d.f. \\
\hline & & & Cross-section random & & 16.270342 & \\
\hline \multicolumn{7}{|c|}{ Dependent Variable: HS } \\
\hline \multicolumn{7}{|c|}{ Method: Panel Least Squares } \\
\hline Date: 07/19/18 Tim & & & \multicolumn{4}{|c|}{ Cross-section random effects test comparisons: } \\
\hline \multicolumn{7}{|l|}{ Sample: 20142015} \\
\hline Periods included: 2 & & & Variable & Fixed & Random & Var(Diff.) \\
\hline \multicolumn{7}{|c|}{ Cross-sections included: 15} \\
\hline \multirow{2}{*}{\multicolumn{3}{|c|}{ Total panel (balanced) observations: 30}} & DIV & 0.424431 & 16.383058 & 160.235013 \\
\hline & & & GAIN & 4.633660 & 5.888545 & 0.204885 \\
\hline Variable & Coefficient & Std. Error & \multicolumn{4}{|l|}{$\Longrightarrow$} \\
\hline $\mathrm{C}$ & 75.07599 & 738.7899 & \multicolumn{4}{|c|}{ Crosbedefelon randOrQ k9Rects test equation: } \\
\hline DIV & 14.12970 & 4.277649 & \multicolumn{4}{|l|}{ Depe803datt5Variable:(1087 } \\
\hline GAIN & 13.37693 & 2.725857 & \multicolumn{4}{|l|}{ 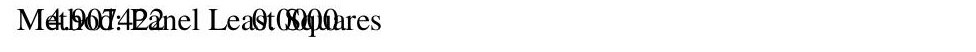 } \\
\hline & & & \multicolumn{4}{|l|}{$=15: 17$} \\
\hline R-squared & 0.667021 & Mean dependent $\mathrm{v}$ & \multicolumn{4}{|l|}{ vasample: 2014201447.400} \\
\hline Adjusted R-squared & 0.642356 & S.D. dependent vat & \multicolumn{4}{|l|}{${ }^{\mathrm{ar}}$ Periods included: 406.027} \\
\hline S.E. of regression & 2395.738 & Akaike info criteri & \multicolumn{4}{|l|}{ iqu ${ }_{\text {ross-sections included: } 15} 18}$. \\
\hline Sum squared resid & $1.55 \mathrm{E}+08$ & Schwarz criterion & \multicolumn{4}{|c|}{ Total panel (balanced) 1833 servations: 30} \\
\hline Log likelihood & -274.4311 & Hannan-Quinn crit & 18.54024 & & & \\
\hline F-statistic & 27.04311 & Durbin-Watson sta & Variabđe 951607 & Coefficient & Std. Error & t-Statis \\
\hline Prob(F-statistic) & \multicolumn{2}{|l|}{0.000000} & $\mathrm{C}$ & 3405.935 & 1393.261 & 2.4445 \\
\hline \multirow{2}{*}{\multicolumn{3}{|c|}{ Sumber: Ouput eviews 9 (2018) }} & DIV & 0.424431 & 13.40414 & 0.0316 \\
\hline & & & GAIN & 4.633660 & 1.357772 & 3.4126 \\
\hline
\end{tabular}


Lagrange Multiplier Tests for Random Effects Null hypotheses: No effects

Alternative hypotheses: Two-sided (Breusch-Pagan) and one-sided

(all others) alternatives

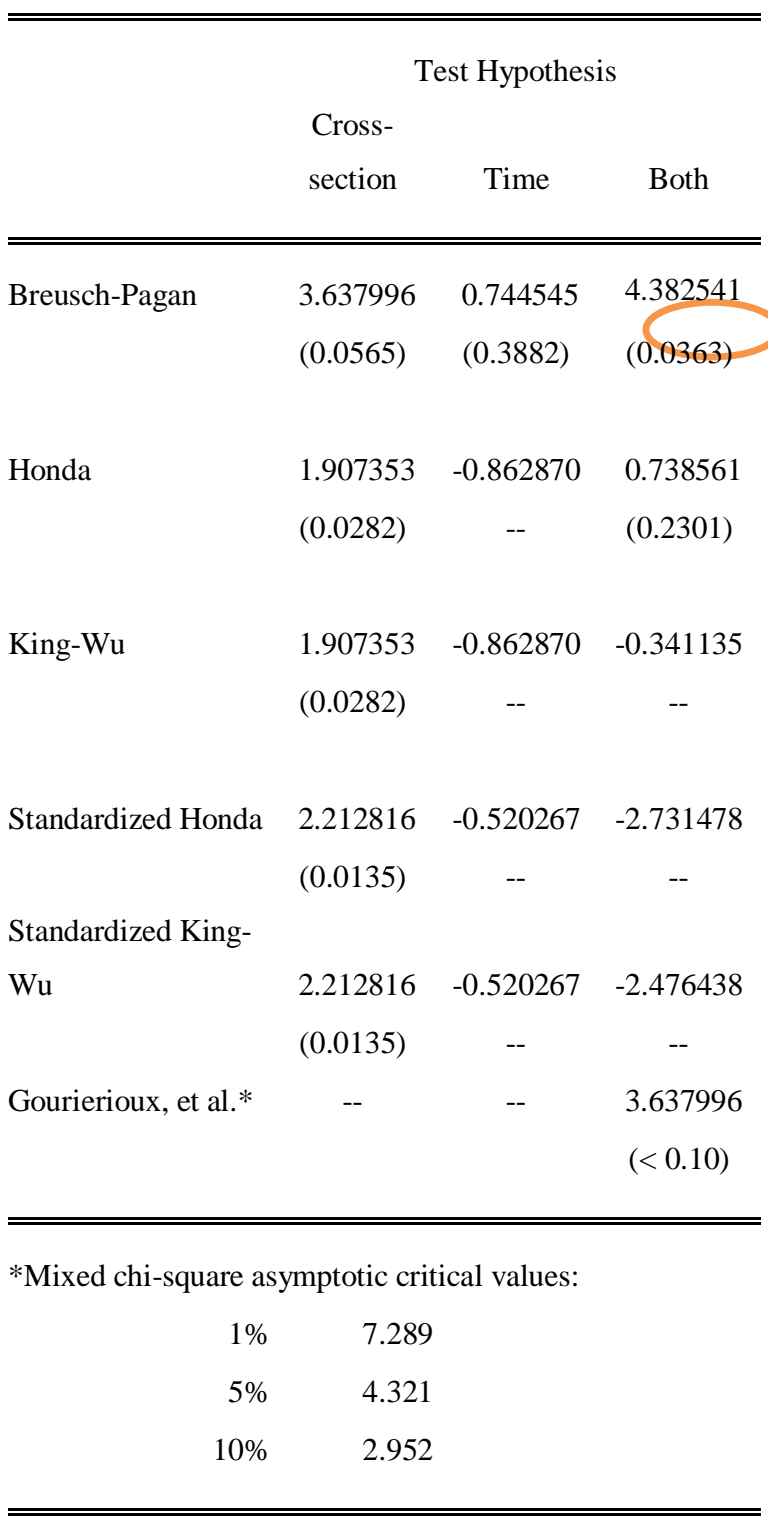

Effects Specification
Lisa Kustina, Otika Safitri dan Samsul Anwar Prob(F-statistic) 0.000000

Sumber: ouput eviews 9 (2018)

Dari tampilan output eviews diatas dapat dilihat hasil correlation random effect atau hausman test untuk model ini memiliki nilai probabilitas F lebih kecil dari pada Alpha $(0,05)$ sehingga random effect ditolak dan Fixed effect diterima, model yang sesuai dari hasil ini yaitu fixed effect (Karena nilai probabilitas $\mathrm{F}$ sebesar $0,0003<0,05$ ).

\section{Uji Lagrange Multiple}

Hasil Uji Lagrange Multiple

Dari hasil output diatas dapat dilihat bahwa nilai probabilitas Breusch pagan sebesar $0,0363<0,05$ yang berarti bahwa common effect ditolak. Dengan demikian, model yang lebih baik diantara common effect dan random effect adalah model random effect. Dalam uji chow dan uji hausman yang telah dilakukan sebelumnya telah menunjukan bahwa model fixed effect lebih tepat digunakan dalam prediksi bentuk regresi dalam penelitian ini dibandingkan dengan model common effect maupun random effect sehingga model fixed effect adalah model yang paling tepat digunakan dalam penelitian ini.

Cross-section fixed (dummy variables)

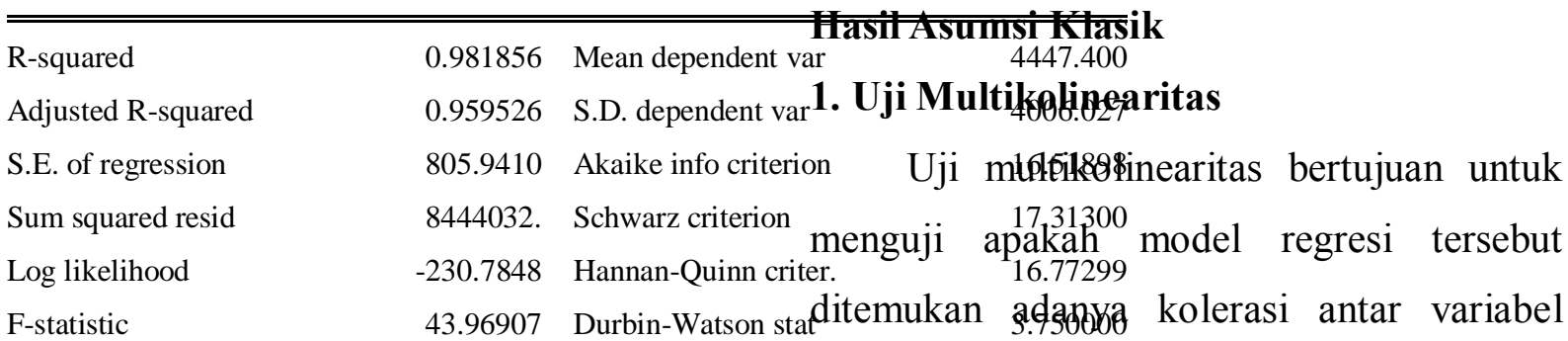


Lisa Kustina, Otika Safitri dan Samsul Anwar

independen. Untuk mendeteksi apakah ada atau tidaknya multikoliniearitas didalam model regresi dapat dilihat dari nilai tolerance dan VIF, dimana tidak terjadi multikolinearitas jika nilai Centered $\mathrm{VIF}<10$. Hasil uji multikolinearitas dapat dilihat pada tabel 5.6 sebagai berikut :

\section{Hasil Uji Multikolinearitas}

Variance Inflation Factors

Date: 08/28/18 Time: 11:05

Sample: 130

Included observations: 30

\begin{tabular}{cccc}
\hline \hline & & & \\
Variable & Coefficient & Uncentered & Centered \\
& Variance & VIF & VIF \\
C & 1066861. & 2.408953 & \\
DIV & 6.771553 & 1.512449 & 1.200366 \\
GAIN & 12.51591 & 2.890719 & 1.200366 \\
\hline \hline
\end{tabular}

Sumber: output eviews 9 (2018)

Berdasarkan tabel diatas, bahwa nilai Centered $\mathrm{VIF}<10$ yaitu pada variabel dividen dengan nilai VIF sebesar 1,2003, pada variabel capital gain sebesar 1,2003. Hal ini tidak terjadi multikoleniaritas dan layak dalam menggunakan regresi linear berganda.

\section{Uji Autokolerasi}

Uji autokolerasi digunakan untuk suatu tujuan yaitu mengetahui ada tidaknya kolerasi antar anggota serangkaian data menurut ruang dan waktu. Dalam pembahasan ini akan menggunakan metode Durbin watson, dengan nilai tingkat probabilitas jika $>0.05$ berarti tidak terjadi autokolerasi dan sebaliknya untuk mengetahui uji model yang digunakan terbebas dari gangguan autokolerasi dapat diketahui dari hasil berikut ini:

Hasil Uji Autokolerasi

Breusch-Godfrey Serial Correlation LM Test:

\begin{tabular}{lll}
\hline \hline F-statistic & 2.790608 & Prob. F(2,25) \\
Obs*R-squared & 5.475142 & Prob. Chi-Square(2)
\end{tabular}

Test Equation:

Dependent Variable: RESID

Method: Least Squares

Date: 07/19/18 Time: 13:01

Sample: 130

Included observations: 30

Presample missing value lagged residuals set to zero.

\begin{tabular}{|c|c|c|c|}
\hline Variable & Coefficient & Std. Error & $\mathrm{t}$-Statistic \\
\hline $\mathrm{C}$ & 360.1546 & 1039.454 & 0.346485 \\
\hline DIV & 0.544875 & 2.464059 & 0.221129 \\
\hline GAIN & -1.914141 & 3.743989 & -0.511257 \\
\hline RESID(-1) & 0.091278 & 0.203214 & 0.449171 \\
\hline $\operatorname{RESID}(-2)$ & 0.424714 & 0.183461 & 2.315013 \\
\hline R-squared & 0.182505 & \multirow{7}{*}{\multicolumn{2}{|c|}{$\begin{array}{l}\text { Mean dependent var } \\
\text { S.D. dependent var } \\
\text { Akaike info criterion } \\
\text { Schwarz criterion } \\
\text { Hannan-Quinn criter. } \\
\text { Durbin-Watson stat }\end{array}$}} \\
\hline Adjusted R-squared & 0.051705 & & \\
\hline S.E. of regression & 3424.955 & & \\
\hline Sum squared resid & $2.93 \mathrm{E}+08$ & & \\
\hline Log likelihood & -283.9986 & & \\
\hline F-statistic & 1.395304 & & \\
\hline Prob(F-statistic) & 0.264310 & & \\
\hline
\end{tabular}

Sumber: output eviews 9 (2018)

Pada penelitian ini menunjukan bahwa nilai prob $\mathrm{f}(2,25)$ sebesar 0.0806 dapat juga disebut sebagai nilai probabilitas f hitung. Nilai probabilitas f hitung lebih besar dari tingkat alpha $0.05(5 \%)$ sehingga berdasarkan uji hipotesis $\mathrm{H} 0$ diterima yang artinya tidak terjadi autokolerasi. Selain menggunakan LM Test, penelitian ini menggunakan Durbin Watson, hasil pengujian autokolerasi metode durbin watson dengan bantuan software 
Lisa Kustina, Otika Safitri dan Samsul Anwar

eviews 9 diperoleh nilai durbin watson sebesar 1.939531. Berdasarkan tabel durbin watson, dengan jumlah sample $(n)=30$ dan jumlah variabel bebas $(k)=2$ diperoleh nilai $\mathrm{D} 1$ sebesar 1.2837 dan nilai du sebesar 1.5666 sehingga dapat disimpulkan bahwa durbin watson hitung terletak pada daerah tidak ada autokolerasi atau memenuhi kriteria $\mathrm{du}<\mathrm{dw}<4$-du yaitu $1.5666<1.939531<2.4444$ atau $\mathrm{H} 0$ diterima yang artinya tidak terjadi autokolerasi.

\section{Uji Normalitas}

Uji normalitas bertujuan untuk menguji apakah dalam model regresi, variabel pengganggu atau residul memiliki distribusi normal. Model regresi dapat dikatakan baik apabila memiliki distribusi data normal atau mendekati normal.

Hasil Uji Normalitas
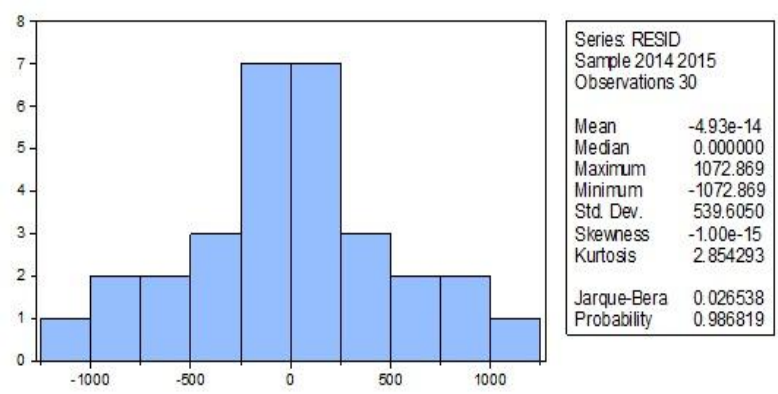

Sumber: output eviews 9 (2018)

Dengan melihat nilai probabilitas Jarque Bera sebesar 0,9868 yang lebih tinggi dari tingkat signifikansi yang digunakan dalam penelitian ini yaitu 0,05 , maka dapat disimpulkan bahwa model regresi yang digunakan dalam penelitian ini mempunyai data yang berdistribusi dengan normal.

\section{Uji Heteroskedastisitas}

Uji heteroskedastisitas bertujuan untuk menguji apakah dalam model regresi terjadi ketidaksamaan variance dari residual satu ke pengamatan yang lain. Cara untuk mendeteksi ada atau tidaknya heteroskedastisitas yaitu dengan melihat nilai prob $F$ Statistik ( $F$ hitung). Apabila nilai prob f hitung lebih besar dari tingkat alpha $0,05(5 \%)$ maka $\mathrm{H} 0$ diterima yang artinya tidak terjadi heteroskedastisitas, sedangkan apabila nilai prob $\mathrm{F}$ hitung lebih kecil dari tingkat alpha $0,05(5 \%)$ maka $\mathrm{H} 0$ ditolak yang artinya terjadi heteroskedastisitas. Oleh karena itu metode uji heteroskedastisitas pada penelitian ini yang akan dilakukan yaitu white.

Dari gambar dibawah terlihat bahwa nilai probability f hitung sebesar 0.10 lebih besar dari tingkat alpha $0.05(5 \%)$ maka $\mathrm{H} 0$ diterima yang artinya tidak terjadi heteroskedastisitas. Hal ini dapat disimpulkan bahwa tidak terjadi masalah heteroskedastisitas.

Hasil Uji heteroskedastisitas

\begin{tabular}{lll} 
Heteroskedasticity Test: White & \\
\hline \hline F-statistic $\cdots$ & 2.405068 & Prob. F(2,27) \\
Obs*R-squared & 4.536418 & Prob. Chi-Square(2) \\
Scaled explained SS & 4.816470 & Prob. Chi-Square(2)
\end{tabular}

Test Equation:

Dependent Variable: RESID ${ }^{\wedge} 2$

Method: Least Squares 
Lisa Kustina, Otika Safitri dan Samsul Anwar

Date: 08/26/18 Time: 23:34

Sample: 130

Included observations: 30
Cross-sections included: 15

Total panel (balanced) observations: 30

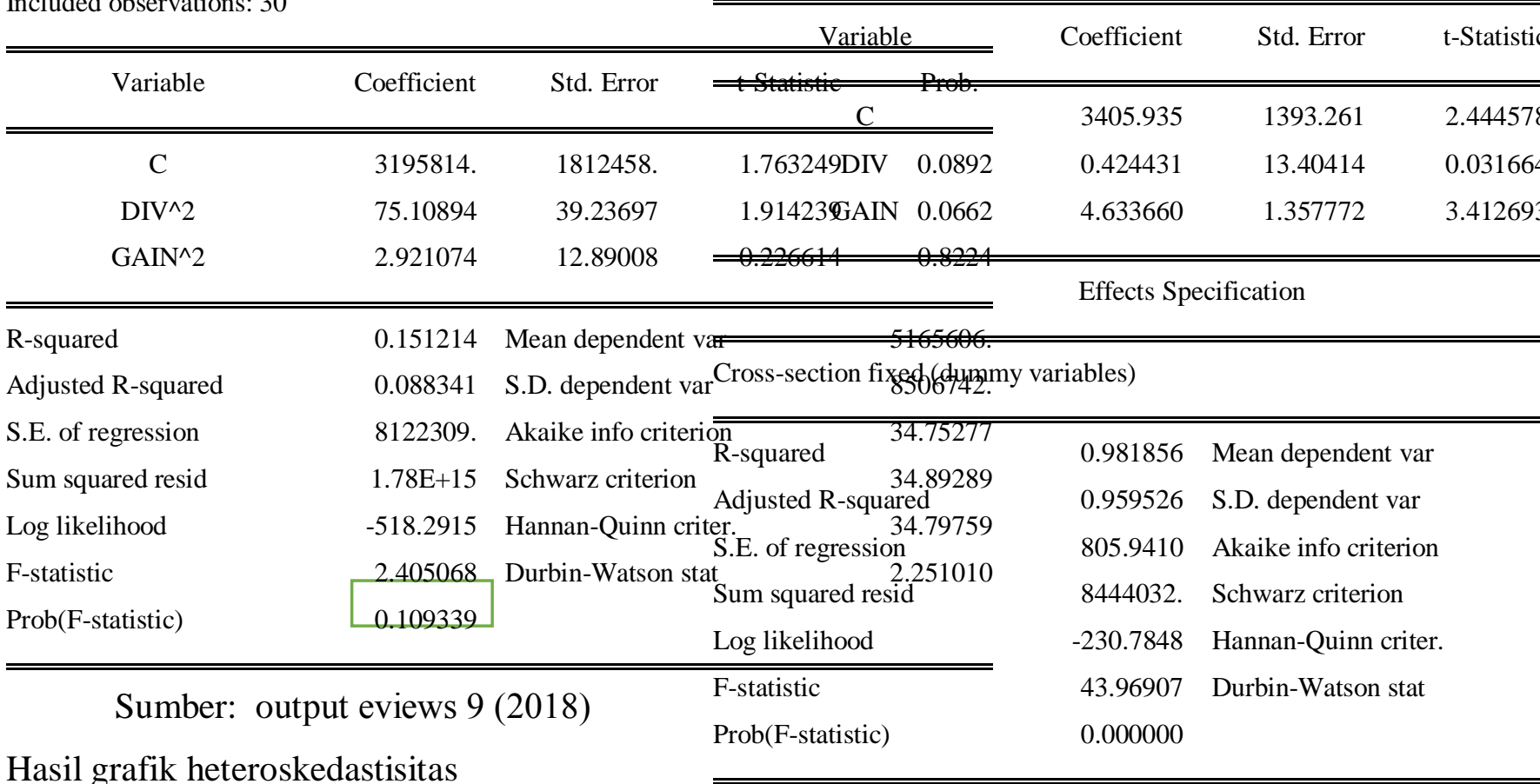

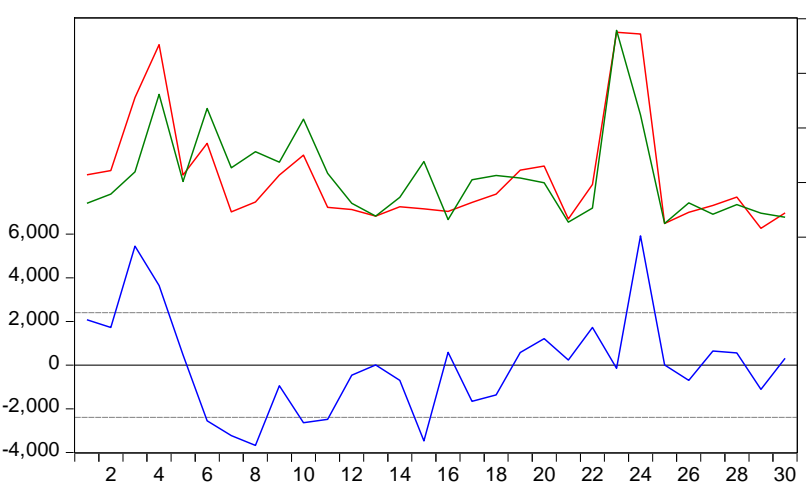

- Residual _- Actual _ Fitted

Sumber : eviews 9 (2018)

Dengan melihat grafik diatas, diduga tidak terjadi heteroskedastisitas, dikarenakan residual tidak membentuk pola tertentu.

\section{Pengujian Hipotesis}

Hasil Uji Hipotesis

Dependent Variable: HS

Method: Panel Least Squares

Date: 07/19/18 Time: 15:13

Sample: 20142015

Periods included: 2
S.pprnber: output eviews 9 (2018)

12,000

8,000

$-4,000$

Dari tabel tersebut diperoleh nilai $t_{\text {hitung }}$ duntuk masing masing variabel dividen, capital gain dan harga saham. Sedangkan nilai $t_{\text {tabel }}$ diperoleh dari degree of freedom $(\mathrm{df})=\mathrm{n}$ $(\mathrm{k}+1)$, dalam hal ini $\mathrm{n}$ adalah jumlah sample, $\mathrm{k}$ adalah jumlah variabel independen. Pada penelitian ini $n=30, k=2$ dan besarnya $\mathrm{df}$ dapat dihitung 30-(2+1)=27 dan $\alpha=0,05$ didapat nilai $t_{\text {tabel }}$ 2,052. Dari hasil uji hipotesis pada tabel 5.7 dapat dijelaskan sebagai berikut:

\section{Hasil uji hipotesis $1\left(\mathrm{H}_{1}\right)$}

Uji hipotesis satu digunakan untuk menguji pengaruh kebijakan deviden terhadap harga saham. Dari tabel diperoleh $t_{\text {hitung }}$ sebesar 0,031 dengan tanda koefisien positif. Dengan nilai $t_{\text {tabel }} 2,052$ pada tingkat 
Lisa Kustina, Otika Safitri dan Samsul Anwar

signifikan $5 \%$. Dari table dapat dilihat bahwa thitung sebesar 0,0316 dan ttabel sebesar 2,052 pada signifikan 5\% $(\alpha=0,05)$. Nilai $t_{\text {hitung }}$ lebih kecil dari $t_{\text {tabel }}(0,031<2,052)$ sehingga dapat disimpulkan bahwa H1 ditolak, artinya kebijakan dividen tidak berpengaruh terhadap harga saham.

Berdasarkan hasil pada table diatas uji regresi parsial (Uji t) menunjukan bahwa nilai koefisien regresi variable dividen sebesar 0,4244 dengan $\mathrm{t}$ sebesar 0,03166 dan signifikansi $0,9752>0,005$ hal ini menunjukan tidak ada pengaruh secara signifikan kebijakan dividen terhadap harga saham. Hasil penelitian ini sama dengan penelitian yang dilakukan oleh Natalia \& Kalangi (2016), menghasilkan kesimpulan selisih harga saham tidak berbeda secara signifikan dengan dividen per lembar saham.

\section{Hasil uji hipotesis $2\left(\mathbf{H}_{2}\right)$}

Uji hipotesis dua digunakan untuk menguji pengaruh harga saham terhadap capital gain. Dari tabel diperoleh $t_{\text {hitung }}$ sebesar 3,412 dengan tanda koefisien positif. Dengan nilai $t_{\text {tabel }} 2,052$ pada tingkat signifikan $5 \%$. Dari table dapat dilihat bahwa thitung sebesar 3,412 dan ttabel sebesar 2,052 pada signifikan $5 \%(\alpha=0,05)$. Nilai $t_{\text {hitung }}$ lebih besar dari tabel $(3,412<2,052)$ sehingga dapat disimpulkan bahwa H2 diterima, artinya capital gain berpengaruh terhadap harga saham.

Berdasarkan hasil pada table diatas uji regresi parsial (Uji t) menunjukan bahwa nilai koefisien regresi variable capital gain sebesar 4,6334 dengan $t$ sebesar 3,4126 dan signifikansi $0,0046<0,005$ hal ini menunjukan adanya pengaruh secara signifikan capital gain terhadap harga saham. Hasil penelitian ini sama dengan penelitian yang dilakukan oleh Kurniawan \& Surihadi (2015), menyatakan bahwa ada pengaruh secara bersama sama variabel harga saham, ukuran perusahaan dan risiko saham terhadap required of return saham pada industry manufaktur.

\section{Hasil Uji Determinasi}

Hasil Uji Determinasi $\left(\mathrm{R}^{2}\right)$

Cross-section fixed (dummy variables)

\begin{tabular}{lrl}
\hline \hline R-squared & 0.981856 & Mean dependent var \\
Adjusted R-squared & 0.959526 & S.D. dependent var \\
S.E. of regression & 805.9410 & Akaike info criterion \\
Sum squared resid & 8444032. & Schwarz criterion \\
Log likelihood & -230.7848 & Hannan-Quinn criter. \\
F-statistic & 43.96907 & Durbin-Watson stat \\
Prob(F-statistic) & 0.000000 &
\end{tabular}

Sumber: output eviews 9 (2018)

Analisis koefisien determinasi digunakan untuk mengetahui persentase dividen dan capital gain terhadap harga saham. Dan berdasarkan table output model fixed effect diatas dapat diketahui bahwa nilai R Squared sebesar 0,9818 artinya secara bersama sama variable kebijakan dividen dan capital gain mempunyai kontribusi menjelaskan harga saham sebesar 98,1\% sedangkan sisanya sebesar 1,9\% dijelaskan 
Lisa Kustina, Otika Safitri dan Samsul Anwar

oleh variable lain yang tidak diteliti atau tidak dimasukan dalam model penelitian ini. Untuk koefisien determinasi yang disesuaikan (R2 adjusted) menunjukan angka 0,959, yang berarti bahwa setelah mempertimbangkan derajat kebebasan model yang digunakan, seluruh variabel independen yang digunakan dalam penelitian ini menjelaskan harga saham sebesar 95,9\%.

\section{KESIMPULAN}

Variabel dividen tidak berpengaruh secara signifikan terhadap harga saham. Hal ini ditunjukan dengan nilai signifikansi $0,9752>0,005$. Ketidak signifikanya variabel dividen terhadadap harga saham kemungkinan karena jumlah dividen yang diberikan kecil, sehingga para investor lebih tertarik terhadap capital gain.

Variabel capital gain berpengaruh secara signifikan terhadap harga saham. Hal ini ditunjukan dengan nilai signifikansi $0,0046<0,005$, artinya semakin tinggi capital gain yang didapat maka semakin tinggi harga saham perusahaan. Karena dengan semakin tingginya capital gain maka semakin banyak investor akan tertarik untuk membeli saham dan membuat harga saham naik. Jadi jika capital gain naik maka harga saham akan naik juga.

\section{DAFTAR PUSTAKA}

Abdullah M, and Nazamul Hoque. (2013). Stock pricereaction to dividend announcemeny: the case of Bangladesh capital market, Journal of Economic and sustainable development.

Annisa Prili B. S, Retnani, \& Endang D. (2017). Pengaruh kinerja keuangan, kebijakan dividen, dan ukuran perusahaan terhadap harga saham LQ45, Jurnal Ilmu dan Riset Akuntansi No.4.

Ariyani Indriastuti dan Zumrotun Nafiah, 2017, Pengaruh volume perdagangan, kurs dan risiko pasar terhadap return saham, Jurnal STIE Semarang Vol 9 No. 1

Desiree Natalia P dan Lintje Kalangi. (2016). Analisis pengaruh dividen terhadap harga pasar saham emiten lq 45Pada bursa efek Indonesia, Jurnal EMBA Vol.4 No.4 Hal. 803-814

Devitia putri Nilamsari, \& Supatmi. (2015). Dampak intellectual capital terhadap capital gain pada lembaga keuangan, UNISSULA ISSN 2302-9791 Vol.2 No.1.

Dovi Kurniawan dan Heru Surihadi. (2015). Pengaruh harga saham, ukuran perusahaan dan resiko saham terhadap required return saham, Jurnal ilmu dan riset manajemen. 
Lisa Kustina, Otika Safitri dan Samsul Anwar

Erdianza, Septian Effendi, \& Hermanto, Rescyana Putri Hutami. (2012). Pengaruh Suwardi B. (2017). Pengaruh rasio keuangan dan volume perdagangan terhadap return saham, Jurnal Ilmu dan Riset Akuntansi No.11.

Fatkur rahmawati. (2017). Pengaruh kebijakan dividen dan keputusan investasi terhadap harga saham pada perusahaan transportasi yang terdaftar dibursa efek Indonesia periode 2009-2014, Jurnal FISIP Volume 4 No. 2

Ina Rinati. (2011). Pengaruh net profit margin (npm), return on assets (roa) dan return on equity (roe) terhadap harga saham pada perusahaan yang tercantum dalam indeks lq45, jurnal manajemen dan akuntansi

Maya Melani. (2017). Pengaruh Faktor Fundamental Terhadap Harga Saham Pada Industri Makanan Dan Minuman Yang Terdaftar Di Bursa Efek Indonesia, Procedings Universitas Widyatama

Nur Aminah, Rina Arifati dan Agus Supriyanto, 2016, Pengaruh Deviden Per Share, Return On Equity, Net Profit Margin, Return On Investment an Return On Asset Terhadap Harga Saham Pada Perusahaan Real Estate Dan Property Yang Terdaftar Di Bursa Efek Indonesia Periode Tahun 2011-2013, Journal Of Accounting, Volume 2 No.2.

Dividend Per Share, Return On Equity Dan Net Profit Margin Terhadap Harga Saham Perusahaaan Industri Manufaktur Yang Tercatat Di Bursa Efek Indonesia Periode 2006-2010, Jurnal Nominal / Volume I No.1.

Rescyana Putri Hutami. (2012). Pengaruh Dividend Per Share, Return On Equity Dan Net Profit Margin Terhadap Harga Saham Perusahaaan Industri Manufaktur Yang Tercatat Di Bursa Efek Indonesia Periode 2006-2010, Jurnal Nominal / Volume I No.1.

Wiradharma, Made Swastyastu., Yuniarta, Gede Ali dan Atmadja, Ananta Wikrama Tungga. (2014). FaktorFaktor Yang Mempengaruhi Kebijakan DPR Yang Terdaftar Di Bursa Efek Indonesia, Jurnal Akuntansi Universitas Volume 2 No 1. 